"Policies for Happiness"

Oxford University Press

Stefano Bartolini (bartolinist@unisi.it)

\title{
POLICY CONSEQUENCES OF HAPPINESS RESEARCH
}

by

\author{
Bruno S. Frey \\ University of Warwick, UK \\ and \\ Alois Stutzer** \\ University of Basel, Switzerland \\ Zeppelin University, Germany
}

(Revised version: June 22, 2011 / updated version: June 20, 2013)

\begin{abstract}
Based on the economic analysis of subjective well-being, policy proposals in two areas, i.e. unemployment and status seeking behavior have been raised. We discuss the suggestion that due to the high psychic costs of individual unemployment, unemployed people should be helped more. Considerations refer to the functionality of experienced pressure in order to maintain a generous benefit system, the consequences of employment protection for employment and the missing institutional approach. The proposal of taxing status seeking in relative income and consumption is assessed based on traditional distorting effects like tax evasion and working in the shadow economy as well as based on the switching to status competition in other (potentially less productive) dimensions. An alternative perspective would compare institutions in their capacity to deal with individuals' positional concerns.
\end{abstract}

Keywords: positional externalities, public policy, subjective well-being, unemployment, taxation

- Bruno S. Frey: Department of Economics, University of Zurich, Hottingerstrasse 10, CH-8032 Zurich, Switzerland. Phone: +41 (0)44 63437 30, fax: +41 (0)44 63435 99, email: bruno.frey@econ.uzh.ch.

** Alois Stutzer: Department of Business and Economics, University of Basel, Peter Merian-Weg 6, CH-4002 Basel, Switzerland. Phone: +41 (0)61 26733 61, fax: +41 (0)61 26733 40, email: alois.stutzer@unibas.ch.

Both authors are also associated with CREMA - Center for Research in Economics, Management and the Arts, Switzerland. 
Only a few years ago, most economists took it for granted that utility cannot possibly be measured, and not even reasonably be approximated. Things have dramatically changed: Happiness research has made great progress, with economists playing a leading role. In certain respects the changes may be interpreted as "revolutionary" (as argued in Frey 2008). Not surprisingly, the economics of happiness has become a "hot" topic in which many economists engage, particularly young ones. This is an indication in which direction the discipline of economics is likely to evolve.

There are several surveys of the state of happiness economics available in the form of journal articles (e.g. Di Tella and MacCulloch 2006, Frey and Stutzer 2002b, Stutzer and Frey 2010) and books (e.g., Bruni and Porta 2005, 2007, Easterlin 2010, Frey and Stutzer 2002a, 2013, Layard 2005, van Praag and Ferrer-i-Carbonell 2004). This article therefore does not intend to provide a survey of the state of research. Rather it deals with specific policy issues related to the new insights gained. The field is vast. It ranges from the fundamental question whether happiness is the ultimate goal of people, and whether other goals such as loyalty, responsibility, self-esteem, freedom, or personal development may also matter to people, and whether it can be subsumed under the label of an extended concept of happiness. We leave this issue open here and focus on more practical, economic policy aspects following from empirical happiness research. Thereby we are interpreting measures of reported life satisfaction and happiness as proxy indicators for individual welfare.

We restrict ourselves to two issues that exemplify well the challenges faced in economics by the new insights gained.

The first issue refers to unemployment. Traditionally, economists considered unemployment as a social bad. The economic policy proposals made by Keynes and his followers were an effort to overcome this ill and to establish full employment. But things changed dramatically with the advent of new classical macroeconomics. This school argues that all unemployment is voluntary: those not working just refuse to do so at the prevailing wage rate. The most important reason why the reservation wage is higher than the prevailing wage is that unemployment benefits are too high. People prefer not to work and to cash in these benefits. We will show that the results of happiness research in economics differ in two significant respects: (1) Unemployed people are much less satisfied with life than those in work, even if the lower income available to them is statistically taken into account. For people in the work force, not 
to work, or to have more leisure, is on average not a beneficial alternative but rather imposes significant psychic costs. (2) Unemployment reduces the subjective wellbeing not only of those persons actually out of work or unemployed but also those in work.

The second issue refers to the importance of status or relative position as determinants of people's happiness. Happiness research suggests that it is a basic human trait that individuals compare themselves to others in a better position. In particular, they suffer a loss in well-being because they compare themselves to persons with higher income. This effect can be mitigated or even overcome by heavily taxing high-income earners. We discuss whether such a proposal makes sense.

The first section deals with the new insights concerning unemployment. The second section discusses the taxation proposal to deal with the negative externalities produced by status considerations. The last section draws conclusions.

\section{New Insights into Unemployment}

\section{Unemployment Reduces Subjective Well-Being}

Unemployment first of all reduces the individual well-being of those personally affected. In their innovative work for Britain, Clark and Oswald (1994, p. 655) summarize their results as follows: "Joblessness depresses well-being more than any other single characteristic including important negative ones such as divorce and separation." For Germany, based on individual panel data, Winkelmann and Winkelmann (1998) find a negative effect of personal unemployment on life satisfaction that would require a sevenfold increase in income to compensate. Importantly, in these two analyses, indirect effects (like income losses) that may, but need not, accompany personal unemployment are kept constant. Being unemployed therefore has psychic costs over and above the potential decrease in the material living standard. ${ }^{1}$

High unemployment rates also have non-negligible effects on people who are not personally affected by unemployment. Based on survey data from population samples

\footnotetext{
${ }^{1}$ For references and a discussion of psychological and social factors determining the drop in life satisfaction of people who become unemployed, see Frey and Stutzer (2002a: 95-109). The specific effect of social work norms on unemployed people's subjective well-being is studied empirically in Clark (2003) and Stutzer and Lalive (2004).
} 
from European Union member countries between 1975 and 1992, Di Tella, MacCulloch, and Oswald (2003) show that aggregate unemployment decreases average reported life satisfaction even if personal unemployment is kept constant. The cumulative costs of unemployment are substantial. According to their estimation, the average individual in the working population would have to be compensated with approximately $\$ 200$ to offset the loss in life satisfaction caused by a typical U.S.-size recession (that is, a recession that entails a 1.5 percentage point increase in the unemployment rate). ${ }^{2}$

The question that naturally arises is why even people who are employed feel so much less satisfied with their lives when unemployment rates increase.

\section{Costs of High Unemployment for the Employed}

The potential reasons that explain why workers' well-being decreases when unemployment rates increase can be divided into two broad categories: First, a high rate of unemployment may have general negative effects on society that affect everybody in a region. Such reasons include not only the direct effects of unemployment on crime and public finances, but also the general increase in income inequality within a society-an increase that may have the effect of triggering workers' empathy with the unemployed. Second, high unemployment rates affect factors specific to people's individual workplaces. These reasons include changes in working hours and salaries and most likely a change in the actual and perceived probability of job loss.

General effects of unemployment on society. Unemployment leads to social problems that affect people in general. For example, higher unemployment has been observed to increase crime (see, for example, Oester and Agell 2007, Raphael and Winter-Ebmer 2001). In Germany, right-wing crime is positively correlated with regional unemployment rates (Falk et al. 2011). If higher crime rates are reflected in lower reported well-being, this contributes to the statistical relationship between unemployment rates and subjective well-being. High unemployment also has fiscal

\footnotetext{
2 Interestingly, there are systematic differences in the experienced reduction in life satisfaction. Di Tella and MacCulloch (2005) find that the sensitivity to unemployment differs according to individuals' political orientation. Left-wing voters care more about unemployment (relative to inflation) than do right-wing voters.
} 
effects that may worry the general population. In particular, if unemployment rates are as high as they were in many European countries in the second half of the 1990s, the fiscal burden may rise to a level that concerns the working population. These general effects are expected to influence all workers alike independent of, for example, their sectoral employment.

People also care about the well-being of others and about inequality within a society. Schwarze and Härpfer (2007) present evidence for Germany that people of all income classes report lower life satisfaction when regional income inequality increases. This may be due to inequality aversion and/or to empathy for the poor. Similarly, if economic shocks increase unemployment, people may care about the fate of the people who experience unemployment, reducing their own sense of well-being.

Effects of unemployment on economic security. High unemployment rates have effects on individuals' contemporaneous and future economic situations. In times of high unemployment, the pressure on salaries increases, leading to lower average wages (see the literature on the wage curve by, for example, Blanchflower and Oswald 1994). Because income correlates positively with people's well-being, depressed salaries lead to a lower life satisfaction in times of high unemployment. Moreover, working conditions may become harsher in times of high unemployment. In particular, actual working hours may rise in recessions as firms cut costs and fear of redundancy and scarcity of alternative job opportunities enable firms to force employees to work more hours than they would prefer (see Stewart and Swaffield 1997, for Britain). This reduces people's leisure time-sometimes without financial compensation.

The above-mentioned effects on salaries and working hours refer to realized consequences. However, high unemployment also affects anticipated economic distress, as, for instance, the probability that a worker may himself experience a spell of unemployment in the future increases. A large literature documents the importance of self-reported job security on individuals' well-being (see, for example, De Witte 1999, Duncan Gallie et al. 1998, Green 2006). Moreover, people may also expect salary decreases, reduced promotion opportunities and fewer possibilities to change jobs. 
In an empirical study Luechinger et al. (2010) isolate the latter source of reduced individual welfare: the negative anticipatory feelings of angst and stress due to economic insecurity. In order to distinguish between general negative externalities of unemployment and changes in economic risks to individuals, workers are studied in two sectors of the economy that differ fundamentally in their exposure to economic shocks - people working in the private sector and those working in the public sector. Public sector employees usually enjoy extended protection from dismissal and work in organizations that very rarely go bankrupt. Thus, for institutional reasons these workers face a reduced risk of losing their jobs in comparison with workers in the private sector. The empirical analysis uses data from the German Socio-Economic Panel for West Germany between 1984 and 2004. During this period, West Germany experienced large differences and fluctuations in regional unemployment rates from around 4 percent to almost 20 percent. These fluctuations in the unemployment rate over a long period of time allow the authors to identify any sectoral differences in workers' sensitivity to unemployment. Moreover, the panel aspect of the data allows to control for individual heterogeneity. The general results show that people working in the private sector are affected more strongly by general economic shocks than are those working in the public sector. The life satisfaction of private sector employees decreases substantially when unemployment rates are high. People working in the public sector experience much smaller changes in their well-being in response to fluctuations in unemployment rates. Private sector employees' life satisfaction is reduced by 0.56 points (on a scale between 0 and 10) when regional unemployment rises from the lowest value in the sample to the highest value - similar to the effect of becoming personally unemployed. In comparison, the negative effect on public sector employees is about a third lower than for private sector employees. For the public servants - a particularly well-protected subgroup of all public sector employees - no negative correlation is found whatsoever between regional unemployment and reported life satisfaction. These findings hold after controlling for differences in the wage structure and working conditions in the two sectors, as well as for demographic characteristics and time-invariant individual heterogeneity. Overall, the results suggest that a substantial fraction of the psychic costs brought about by general unemployment is due to increased economic insecurity. 


\section{Consequences for Economic Policy}

Research on happiness has identified two major differences to standard economics. The first is that unemployment is not simply an underutilization of resources and not simply a decision between choosing to stay employed (at a low wage), and becoming unemployed (with unemployment benefits). Rather, individuals experience a loss in well-being when being unemployed beyond the reduction in income involved. The second major difference to standard economics is that the utility losses experienced go beyond the persons actually unemployed. Persons with a job are also negatively affected by a higher unemployment rate, one important reason being increased economic insecurity.

The two differences imply that unemployment involves greater losses in individuals' welfare than considered so far in economics. Accordingly, we recommend policy choices that give relatively more weight to employment than, for example, inflation and even economic growth if there is a trade-off. However, one should not jump to conclusions with regard to specific policy interventions for at least three reasons.

(1) Reduced subjective well-being of unemployed people in terms of psychic costs due to an internalized work norm or social pressure in areas with a strong social work norm can be considered functional. The psychic costs are functional or even necessary to maintain a generous benefit system financially sustainable.

(2) Based on the evidence cited, no conclusion can be drawn as to whether job protection should be increased. While increased job protection might benefit insiders (see, for example, Clark and Postel-Vinay 2009), it is also likely to make employers more reluctant to hire new workers, leading to longer individual unemployment spells and to higher general unemployment.

(3) Policy recommendations from happiness research (like other research in economics) are of limited value if they are not connected to institutions. The welfare costs of unemployment need to be analyzed for alternative institutional arrangements following a constitutional approach (as proposed in Frey and Stutzer 2012). A comparative analysis provides information to citizens so that they can better pursue their ideal of a social insurance system protecting them against some of the consequences of economic shocks. 
The latter argument together with the existing insights from happiness research in economics puts forward the agenda for future research: Work on the evaluation of labor market institutions should give more weight to their consequences for employed and unemployed individuals' welfare. So far, little is known about the institutions that determine the vulnerability of the economy to shocks in terms of life satisfaction. In a longitudinal sample of the European Union, more generous unemployment benefits are found to correlate positively with subjective well-being in the general population (Di Tella et al. 2003). Based on the same data from the Eurobarometer, the negative effects of individual and general unemployment on reported life satisfaction are found to be larger in countries with low job protection (Becchetti et al. 2010). Future research will extend the scarce but interesting findings in this area.

\section{Status and Taxation}

This section discusses a proposal derived from one of the major results of economic happiness research: People do not value the absolute level of their income but compare their economic standing to others. People try to get ahead of their peers with regard to their income and consumption. Accordingly, they allocate their time, effort and risk taking. While each individual optimizes given his or her preferences, he or she does not take into account that other people are made worse off as their relative standing falls in the individual's effort to gain status. The individual optimization thus tends to lead to a socially wasteful race for ever higher income and consumption, at the end of which everybody is worse off.

In short, positional externalities occur when the rise in one person's rank decreases the utility of other persons. Several economists, notably Layard $(2005,2006)$ and Robert Frank (1999), have emphasized the zero sum nature of social status. When one person's position rises, the relative status of other persons falls correspondingly and the group as a whole, or society, is no better off. When status comes through income and someone is made happier as the result of a salary increase, other persons' income automatically decreases in relative terms. The same happens for specific goods and services important to one's position in society. Someone owning such a good (for instance, a fancy sports car) imposes a negative external effect on all other people who do not own such a good (Frank 2003) and that overall happiness may stay 
constant. In that case, there is a positional treadmill where the effort of any particular person to rise relative to the others does not produce any gain for society overall.

As a result, the expenditure of resources to produce and sell such goods is socially wasteful, because it does not raise social well-being. It then appears beneficial to impose a high tax on higher income and on the consumption of positional goods, to discourage people from engaging in such zero-sum (or even negative-sum) status competition.

The research on happiness has indeed found empirical evidence that an individual's happiness level is reduced when the average income of other persons increases (see e.g. Frey and Stutzer 2002a, chapter 4, Frey 2008, chapter 3) ${ }^{3}$. There is also convincing circumstantial evidence suggesting the same externality with respect to consumption, especially for luxury goods (Frank 1985a, 1997, 1999). ${ }^{4}$

According to standard welfare economics, a tax may be warranted when an activity (here the effort to increase income or consumption) imposes negative external effects on other people. The government should intervene to undo the welfare-decreasing status race. The proposal to (highly) tax positional externalities has been advanced in particular by Frank (1999) and Layard (2006). ${ }^{5}$ In Layard's model, the optimal linear income tax arising from the positional externality is equal to the negative effect of the average income of others on individuals' subjective well-being. This latter effect can be approximated by econometric estimates as has been done for various countries and periods. The proposed tax is substantial, although it must be taken into account that part of the existing taxes may already serve the same purpose.

\footnotetext{
${ }^{3}$ Specific studies are e.g. Stutzer (2004) analyzing the effect of the income level in the community of residence on people's income aspirations and life satisfaction; Luttmer (2005) examining how reported well-being correlates within neighborhood income; de la Garza et al. (2010) estimating subjective well-being as a function of both own and self-reported reference wages; and Winkelmann (2012) analyzing regional variation in income satisfaction as a function of the prevalence of luxury cars in the area. For a survey see Clark, Frijters and Shields (2008).

${ }^{4}$ In economics, the importance of status effects has also been emphasized by Hirsch (1976), Sen (1983), and more recently by Bolton and Ockenfels (2000) and Fehr and Schmidt (1999). Nicholson (1998), Loch, Huberman and Stout (2000) and Huberman, Loch and Önçüler (2004) have provided more specific analyses in the work context.

${ }^{5}$ Studies in the optimal tax framework are e.g. Oswald (1980), Tuomala (1990), Ireland (2001) and Allgood (2006). See also Weisbach (2008).
} 
However, the idea of taxing positional externalities has several limitations.

\section{Ineffective Taxation}

The government may be unable or unwilling to tax income or consumption according to the positional externalities produced. It may well happen that most of the positional externalities remain because the rich have more opportunities to circumvent taxation than the middle and lower classes. Moreover, as a side effect the distribution of the after-tax disposable income would be more unequal.

\section{Welfare Decreasing Effects of Taxation}

The higher tax induces distorting effects in the economy. The negative incentive effect on work effort of the higher taxation of income or consumption is desired, because it internalizes status externalities. However, raising taxes is likely to induce individuals not only to supply less labor in the official economy, but also to evade taxes by switching to the shadow economy (see Schneider and Enste 2000, Enste and Schneider 2002). Cheating on taxes is expected to increase in general. The induced distortions in resource allocation undermine the internalization of status externalities and may cause overall welfare to decrease.

The two aspects just mentioned have been treated extensively in the economic literature and will not be discussed further here. Instead, we emphasize a third aspect that addresses quite a different point.

\section{Individuals as Status Seekers}

As a result of evolution, man is genetically disposed to seek differences in position. Striving for status has been inherited from the early humans (Henrich and Gil-White (2001), a fact well supported by evolutionary anthropology (e.g. Chapais 1991, de Waal 1989); by evolutionary psychology (e.g. Tooby and Cosmides 1992, Barkow 1975, Stevens and Price 2000); and by various sociological theories (e.g. Bales 1953, Blau 1964, Stryker and Stratham 1985, and Ridgeway and Walker 1995, de Botton 2004).

The scholars advocating taxes on positional externalities disregard an important consequence of this general desire for status differences. When one outlet for status is blocked, individuals actively seek other possibilities of differentiating themselves 
from others. Even if the taxation of income and consumption were successful in undoing the negative positional externalities, individuals would try to distinguish themselves from other individuals in other ways. The crucial question is whether the positional externalities in these other dimensions are weaker or stronger (see also Clark in this volume on social comparisons in different life domains). If they are weak, the taxation of income and consumption differences may be warranted. On the other hand, if the negative external effects produced by differences in other ways are strong, the taxation of income and consumption differences may be ineffective or even counterproductive.

\section{The Behavior of Status Seekers}

Individuals actively seek new dimensions for distinction, often in a creative and imaginative way. As discussed above, when the income and consumption dimensions are blocked by high taxation, individuals endeavor to differentiate themselves on other dimension. Here is a selection of some possible dimensions:

Political power. The difference in rank with respect to political position is probably as old as mankind. There have always been "ins" and "outs", "powerful" and "powerless" persons.

Awards. Some people acquire distinction by receiving orders, titles, medals and other conferred signs of distinction (see Frey 2005, 2006), and others receive none.

Education. The differences between individuals in the extent of formal education are large even within one country. They range from a few years of basic education to postgraduate university studies. The better educated clearly have a higher status.

Other activities. Individuals can seek distinction by engaging in activities outside economics and politics. Important ways to acquire distinction are sports, the arts, scholarship, social and voluntary activities, and also merely being a "celebrity".

Leisure. Individuals may seek to distinguish themselves relative to others with respect to the amount of leisure time and the type of activity. Frank and Layard assume that when either income or consumption is taxed, individuals take more time for leisure. It is interesting to note that the evaluation of work time and leisure has changed dramatically over recent centuries. In the $18^{\text {th }}$ and much of the $19^{\text {th }}$ centuries, the upper class distinguished itself by having substantially more leisure than the lower 
class, which had to work extremely long hours. Veblen (1899) therefore called it the "leisure class". Today, the opposite seems to be true. Being overwork is taken as a sign of being important or "in demand", while having time available is considered close to being unemployed.

Ideas of the "good life". Individuals may seek to distinguish themselves by leading a "good life". They may engage in meditation and other philosophical, religious and esoteric endeavors. Buddhism and other Eastern philosophies have recently become popular, and of course there is also a long Christian tradition exemplified by religious orders (such as Cistercians, Trappists or Carthusians). In contrast with some of the other dimensions mentioned above, individuals who practice these philosophies or religions rarely consider themselves to be of "higher rank", but they are certainly aware that they distinguish themselves from other individuals. Indeed, the latter are often willing to accept that those leading a "good life" are superior, and they rarely express any misgivings about this. Few positional externalities appear to be created by resorting to a "good life".

\section{Consequences for Economic Policy}

A first assessment of the question of whether positional externalities due to differences in income and consumption should be (highly) taxed depends on the two well-known effects on work incentives and the capacity and willingness of the government to attain the desired reduction in status seeking behavior via higher taxation. The larger the induced distorting effects of taxation, and the lower the government's ability and willingness, the more damage is done by intervening in the economy via such taxation (see also Weisbach 2008).

Even if the two conditions were fulfilled, the normative case for taxing positional externalities depends on whether individuals seek to re-establish their ingrained desire for status differences by substituting with dimensions that are subject to high positional externalities. The externalities created may even be higher than those for income and consumption. Positional externalities that relate to political positions, awards, education, achievements in sports, the arts and academia, leisure, and to ideas of the good life also have to be taken into account. While some of these dimensions are currently not considered relative (see e.g. Solnick and Hemenway, and Carlsson et al. 2007), they might become more positional if consumption is heavenly taxed. Thus 
the normative case for the taxation of positional externalities in income and consumption becomes weak if people transfer their drive for status to these other dimensions. Moreover, in a dynamic setting, the consequences for the incentives to innovate, and thus to generate positive spillovers, have to be taken into account.

A second assessment of the challenges of positional externalities relates to the constitutional perspective. Research in constitutional economics helps us to identify which institutions serve the goal of preference fulfillment. Thereby happiness research provides insights about how and to what extent institutions have systematic effects on indicators of individual well-being. The focus is thus on institutions rather than specific policy interventions. In our application, the focus ought rather be on the relationship between the fiscal constitution of a jurisdiction and people's subjective well-being than on the optimal tax scheme in terms of happiness.

While we are starting to understand positional externalities as a phenomenon, it is premature to draw policy conclusions as there is a severe lack of comparative institutional analyses that take them into account.

\section{Conclusions}

Happiness research in economics has made great advance. In addition to seeking to explain the determinants and consequences of happiness, more and more effort is made to derive implications for policy. This is a welcome development. However, we have to take care not to run into danger of applying happiness research in a simplistic way. Moreover, we think that it is tempting to apply happiness research in a technocratic way (see also the contribution by Sugden and Teng in this volume). This is best visible in the idea of maximizing aggregate happiness as a social welfare function. This is, however, a mistaken direction to go. It neglects the insights from political economics and fails to reflect the rich insights from happiness research (Frey and Stutzer 2012).

We have alluded to policy consequences in two distinct areas: unemployment and positional externalities. Thereby, we put special emphasis on the limitations with regard to the recommendations we can draw. In particular, happiness research in economics needs to provide further insights about how and to what extent institutions have systematic effects on indicators of individual well-being when, e.g., studying the 
consequences of unemployment and status. The range of institutions under study may include self-binding mechanisms, social norms, private and public law (i.e. the rules of the game) as well as constitutional conditions on how to choose rules.

According to this constitutional view (see also Frey and Stutzer 2012), the results gained from happiness research are taken as inputs into the political process. These inputs then have to prove themselves in political competition and in the discourse among citizens, and between citizens and politicians. As an ideal consequence, people become better able to advance their idea of the good life, individually and collectively. 


\section{References}

Allgood, Sam. (2006). The Marginal Costs and Benefits of Redistributing Income and the Willingness to Pay for Status. Journal of Public Economic Theory 8: 357377.

Bales, Robert F. (1953). The Equilibrium Problem in Small Groups. In: Talcott Parsons, Robert F. Bales, and Edward A. Shils (eds.). Working Papers in the Theory of Action. Glencoe, IL: Free Press: 111-61.

Barkow, Jerome H. (1975). Strategies for Self Esteem and Prestige in Maradi, Niger Republic. In: Thomas R. Williams (ed.). Psychological Anthropology. The Hague: Mouton Publishers: 373-88.

Becchetti, Leonardo, Stefano Castriota and Osea Giuntella (2010). The Effects of Age and Job Protection on the Welfare Costs of Inflation and Unemployment. European Journal of Political Economy 26(1): 137-146.

Blanchflower, David G. and Andrew J. Oswald (1994). The Wage Curve. Cambridge, MA: MIT Press.

Blau, Peter M. (1964). Exchange and Power in Social Life. New York: Wiley.

Bolton, Gary E. and Axel Ockenfels (2000). ERC: A Theory of Equity, Reciprocity, and Competition. American Economic Review 90(1): 166-93.

Bruni, Luigino and Pier Luigi Porta (eds.) (2005). Economics and Happiness. Framing the Analysis. Oxford: Oxford University Press.

Bruni, Luigino and Pier Luigi Porta (eds.) (2007). Handbook on the Economics of Happiness. Cheltenham, UK and Northampton, MA, USA: Edward Elgar.

Carlsson, Fredrik, Olof Johansson-Stenman and Peter Martinsson (2007). Do You Enjoy Having More than Others? Survey Evidence of Positional Goods. Economica 74(296): 586-598.

Chapais, Bernard (1991). Primates and the Origins of Aggression, Power and Politics among Humans. In: James D. Loy and Calvin B. Peters (eds.). Understanding Behavior. Oxford: Oxford University Press: 190-228.

Clark, Andrew E. (2003). Unemployment as a Social Norm: Psychological Evidence from Panel Data. Journal of Labor Economics 21(2): 323-51.

Clark, Andrew, Paul Frijters and Mike Shields (2008). Relative Income, Happiness and Utility: An Explanation for the Easterlin Paradox and Other Puzzles. Journal of Economic Literature 46(1): 95-144.

Clark, Andrew E. and Andrew J. Oswald (1994). Unhappiness and Unemployment. Economic Journal 104(424): 648-59.

Clark, Andrew and Fabien Postel-Vinay (2009). Job Security and Job Protection. Oxford Economic Papers 61(2): 207-239.

De Botton, Alain (2004). Status Anxiety. London: Hamish Hamilton.

de la Garza, Adrián, Giovanni Mastrobuoni, Atsushi Sannabe and Katsunori Yamada (2010). The Relative Utility Hypothesis with and without Self-reported Reference Wages. ISER Discussion Paper No. 798.

de Waal, Frans (1989). Chimpanzee Politics. Baltimore, MD: Johns Hopkins University Press.

De Witte, Hans (1999). "Job Insecurity and Psychological Well-Being: Review of the Literature and Exploration of Some Unresolved Issues." European Journal of Work and Organizational Psychology 8(2): 155-77.

Di Tella, Rafael and Robert MacCulloch (2005). Partisan Social Happiness. Review of Economic Studies, 2005, 72(2), pp. 367-93. 
(2006). Some Use of Happiness Data in Economics. Journal of Economic Perspectives 20(1): 25-46.

Di Tella, Rafael, Robert J. MacCulloch and Andrew J. Oswald (2003). The Macroeconomics of Happiness. Review of Economics and Statistics, 85(4): 809-27.

Duncan Gallie, Michael, Michael White, Yuan Cheng and Mark Tomlinson (1998). Restructuring the Employment Relationship. New York: Oxford University Press.

Easterlin Richard A. (2010). Happiness, Growth, and the Life Cycle. Oxford: Oxford University Press.

Falk, Armin, Andreas Kuhn and Josef Zweimüller (2011). Unemployment and RightWing Extremist Crime. Scandinavian Journal of Economics 113(2): 260-285.

Fehr, Ernst and Klaus M. Schmidt (1999). A Theory of Fairness, Competition, and Cooperation. Quarterly Journal of Economics 114(3): 817-68.

Frank, Robert H. (1985a). Choosing the Right Pond. New York: Oxford University Press.

(1997). The Frame of Reference as a Public Good. Economic Journal 107(445): 1832-47.

(1999). Luxury Fever: Why Money Fails to Satisfy in an Era of Excess. New York, NY: Free Press.

(2003). Are Positional Externalities Different from Other Externalities? Conference on "Why Inequality Matters: Lessons for Policy from the Economics of Happiness". The Brookings Institution, Washington D.C., June 45, 2003.

Frey, Bruno S. (2005). Knight Fever: Towards an Economics of Awards. CREMA Working Paper No. 12, Center for Research in Economics, Management and the Arts, Switzerland.

(2006). Giving and Receiving Awards. Perspectives on Psychological Science 1: 377-388.

(2008). Happiness: A Revolution in Economics. Cambridge, MA. and London: MIT Press.

Frey, Bruno S. and Alois Stutzer (2002a). Happiness and Economics: How the Economy and Institutions Affect Well-Being. Princeton and Oxford: Princeton University Press.

(2002b) What Can Economists Learn from Happiness Research? Journal of Economic Literature 40(2): 402-35.

(2012). The Use of Happiness Research for Public Policy. Social Choice and Welfare 38(4): 659-674.

(eds.) (2013). Recent Developments in the Economics of Happiness. Cheltenham, UK: Edward Elgar.

Green, Francis (2006). Demanding Work. The Paradox of Job Quality in the Affluent Economy. Princeton: Princeton University Press.

Henrich, Joseph and Francisco J. Gil-White (2001). The Evolution of Prestige. Freely Conferred Deference as a Mechanism for Enhancing the Benefits of Cultural Transmission. Evolution of Human Behavior 22: 165-96.

Hirsch, Fred (1976). The Social Limits to Growth. Cambridge, MA: Harvard University Press.

Huberman, Bernarda A., Christoph H. Loch and Ayse Önçüler (2004). Status as a Valued Resource. Social Psychology Quarterly 67(1): 103-14. 
Ireland, Norman J. (2001). Optimal Income Tax in the Presence of Status Effects. Journal of Public Economics 81: 193-212.

Layard, Richard (2005). Happiness: Lessons from a New Science. New York: Penguin.

(2006). Happiness and Public Policy: A Challenge to the Profession. Economic Journal 116: C24-C33.

Loch, Christoph H., Bernardo A. Huberman and Suzanne Stout (2000). Status Competition and Performance in Work Groups. Journal of Economic Behavior and Organization 43(1): 35-55.

Luechinger, Simon, Stephan Meier and Alois Stutzer (2010). Why Does Unemployment Hurt the Employed? Evidence from the Life Satisfaction Gap between the Public and the Private Sector. Journal of Human Resources 45(4): 998-1045

Luttmer, Erzo (2005). Neighbors as Negatives: Relative Earnings and Well-Being. Quarterly Journal of Economics 120(3): 923-1002.

Nicholson, Nigel (1998). How Hardwired is Human Behavior? Harvard Business Review 76(4): 135-147.

Oester, Anna and Jonas Agell (2007). Crime and Unemployment in Turbulent Times. Journal of the European Economic Association 5(4): 752-75.

Oswald, Andrew J. (1983). Altriusm, Jealousy and the Theory of Optimal Non-Linear Taxation. Journal of Public Economics 20: 77-87.

Raphael, Steven and Rudolf Winter-Ebmer (2001). Identifying the Effect of Unemployment on Crime. Journal of Law and Economics 41: 259-83.

Ridgeway, Cecilia L. and Henri A. Walker (1995). Status Structures. In: Karen S. Cook, Gary Alan Fine and James S. House (eds.). Sociological Perspectives on Social Psychology. Upper Saddle River, NJ: Pearson Education: 281-310.

Schneider, Friedrich and Dominik Enste (2000). Increasing Shadow Economy All Over the World - Fiction or Reality? Journal of Economic Literature 38(1): 77114.

Enste, Dominik and Friedrich Schneider (2002). The Shadow Economy: An International Survey. Cambridge, UK: Cambridge University Press.

Schwarze, Johannes and Marco Härpfer (2007). Are People Inequality Averse, and Do They Prefer Redistribution by the State? Evidence from German Longitudinal Data on Life Satisfaction. Journal of Socio-Economics 36: 233-49.

Sen, Amartya K. (1983). Poor, Relatively Speaking. Oxford Economic Papers 35(2): 153-69.

Solnick, Sara J. and David Hemenway (2005). Are Positional Concerns Stronger in Some Domains than in Others? American Economic Review 95(2): 147-151

Stevens, Anthony and John Price (2000). Evolutionary Psychiatry: A New Beginning. London: Routledge.

Stewart, Mark B. and Joanna K. Swaffield (1997). Constraints on the Desired Hours of Work of British Men. Economic Journal 107(441): 520-35.

Stryker, Sheldon and Anne Statham (1985). Symbolic Interaction and Role Theory. In: Gardner Lindzey and Elliot Aronson (eds.). Handbook of Social Psychology. New York, NY: Random House.

Stutzer, Alois (2004). The Role of Income Aspirations in Individual Happiness. Journal of Economic Behavior and Organization 54(1): 89-109.

Stutzer, Alois and Bruno S. Frey (2010). Recent Advances in the Economics of Individual Sujective Well-Being. Social Research 77(2): 679-714. 
Stutzer, Alois and Rafael Lalive (2004). The Role of Social Work Norms in Job Searching and Subjective Well-Being. Journal of the European Economic Association 2(4): 696-719.

Tooby, John and Leda Cosmides (1992). The Psychological Foundations of Culture. In: Jerome H. Barkow, Leda Cosmides and John Tooby (eds.). The Adapted Mind. Oxford: Oxford University Press: 19-136.

Tuomala, Matti (1990). Optimal Income Tax and Redistribution. Oxford: Clarendon Press.

van Praag, Bernard M.S. and Ada Ferrer-i-Carbonell (2004). Happiness Quantified A Satisfaction Calculus Approach. Oxford: Oxford University Press.

Veblen, Thorstein (1899). The Theory of Leisure Class. New York: Modern Library.

Weisbach, David A. (2008). What Does Happiness Research Tell Us About Taxation? Journal of Legal Studies 37(2): 293-324.

Winkelmann, Rainer (2012). Conspicuous Consumption and Satisfaction. Journal of Economic Psychology 33(1): 183-191.

Winkelmann, Rainer and Liliana Winkelmann (1998). Why Are the Unemployed So Unhappy? Evidence from Panel Data. Economica 65(257): 1-15. 